\title{
Visual Inspection Of Photovoltaic Modules Deployed In A 15 Kwp Off-Grid Solar Power System At Hoineno Village
}

\author{
James J. Mauta, Julius Tanesab*, Indranata Panggalo \\ \{jamesjosiasmauta@gmail.com,julius_halan@yahoo.co.id*,indrapanggalo@gmail.com\} \\ Politeknik Negeri Kupang
}

\begin{abstract}
Photovoltaic (PV) modules deployed outdoor are exposed to various environmental conditions which can contribute to degrade their power output. Visual inspection is a well known as an initial method commonly applied to assess degradation modes of PV modules. By applying the method, it was found that the modules installed on the $15 \mathrm{kWp}$ off-grid solar power system at Hoineno village experienced several degradation modes such as snail trails, microcracks, soiling, discoloration, and corrosion. Except soiling factor, the type of degradation is likely attributed to the high temperature and humidity in the village. The effect of dust can be eliminated by performing a cleaning procedure. By doing that, economic losses and permanent degradation on PV modules can be avoided.
\end{abstract}

Keywords: visual inspection, PV modules, permanent degradation, performance degradation

\section{Introduction}

Photovoltaic (PV) module is one of the active solar energy technologies that is developing very fast [1]. It has been applied widely as a source of electrical energy for household appliances, electric vehicles, industrial, and commercial [2]. Because of its reliability, no moving parts, easy operation and maintenance, and continual price decreasing, solar module has been applied as electric power source in the short, medium and long term [1].

Energy produced by solar modules installed in the field can experience a temporary decrease (temporary degradation). Its ability to produce electricity can be restored through certain procedures. Dust or soiling can be the cause of the degradation. Dust/soiling materials block photons that can be converted into electricity. In addition to dust/soiling, the temporary performance degradation can be caused by shading of high objects around the module installation area $[3,4]$ such as trees, buildings or passing clouds.

In addition to temporary degradation, module performance also decreases permanently (permanent degradation) with the increasing of its age. PV module installed outdoor were exposed to varied environmental conditions including temperature, humidity and chemical elements [5]. Permanent degradation is usually characterized by changes in colour, cracks, loss of adhesion of cells, and moisture ingress [6]. 
Similar to the other places, solar modules applied at the Hoineno off-grid PV system also experienced a permanent performance degradation. Initial inspection conducted by the authors in March 2019 found that the performance of silicon-based modules in the system which was assessed based on power output were decrease on a decrease of $12 \%$ from their initial values recorded in 2011.

To investigate the factors behind the permanent degradation, the project owner, the Department of Energy and Mineral Resources (Energi dan Sumber Daya Mineral (ESDM), Nusa Tenggara Timur (NTT) province) conducted a visual inspection in 2014. However, the inspection was not carried out comprehensively. Some parts of the modules affecting their performance were not included during the inspection such as the back side of the modules, the edge of the module, junction boxes, and the modules' wirings.

This study aimed to investigate the factors causing permanent performance degradation. Visual inspection referred to the standard inspection methods issued by the International Energy Agency [7]. This comprehensive inspection covered all the factors triggering permanent degradation in the performance of solar modules. The work was more comprehensive than the previous study conducted by ESDM.

This research is very important because it provides more accurate information for ESDM to determine the reliability of the used modules. High degradation directly leads to loss of power output which have an effect in reducing investment returns. The results of the inspection also could be a reference for the development of off-grid solar power system by ESDM and other institutions in the future. This research is also a clue to claim the product guarantee by ESDM to both the contractor and module manufacturer if there is an improper disability.

\section{Experimental procedure}

Eighty-four PV modules deployed in the $15 \mathrm{kWp}$ off-grid system at Hoineno village for 6 years were observed visually. Layout of the system and electrical specification of the modules as shown in Figure 1 and Table 1, respectively. This study provided a clear information about the degradation factors affected the modules' performance.

Table 1. Electrical specification of PV modules at the Hoineno off-grid system

\begin{tabular}{lr}
\hline Parameters & \\
\hline Maximum power (Pmax) & $180 \mathrm{Wp}$ \\
Voltage @ Pmax (Vmp) & $35,6 \mathrm{~V}$ \\
Current @ Pmax (Imp) & $5,06 \mathrm{~A}$ \\
Short circuit current & $44,1 \mathrm{~V}$ \\
Open circuit voltage & $5,52 \mathrm{~A}$ \\
\hline
\end{tabular}




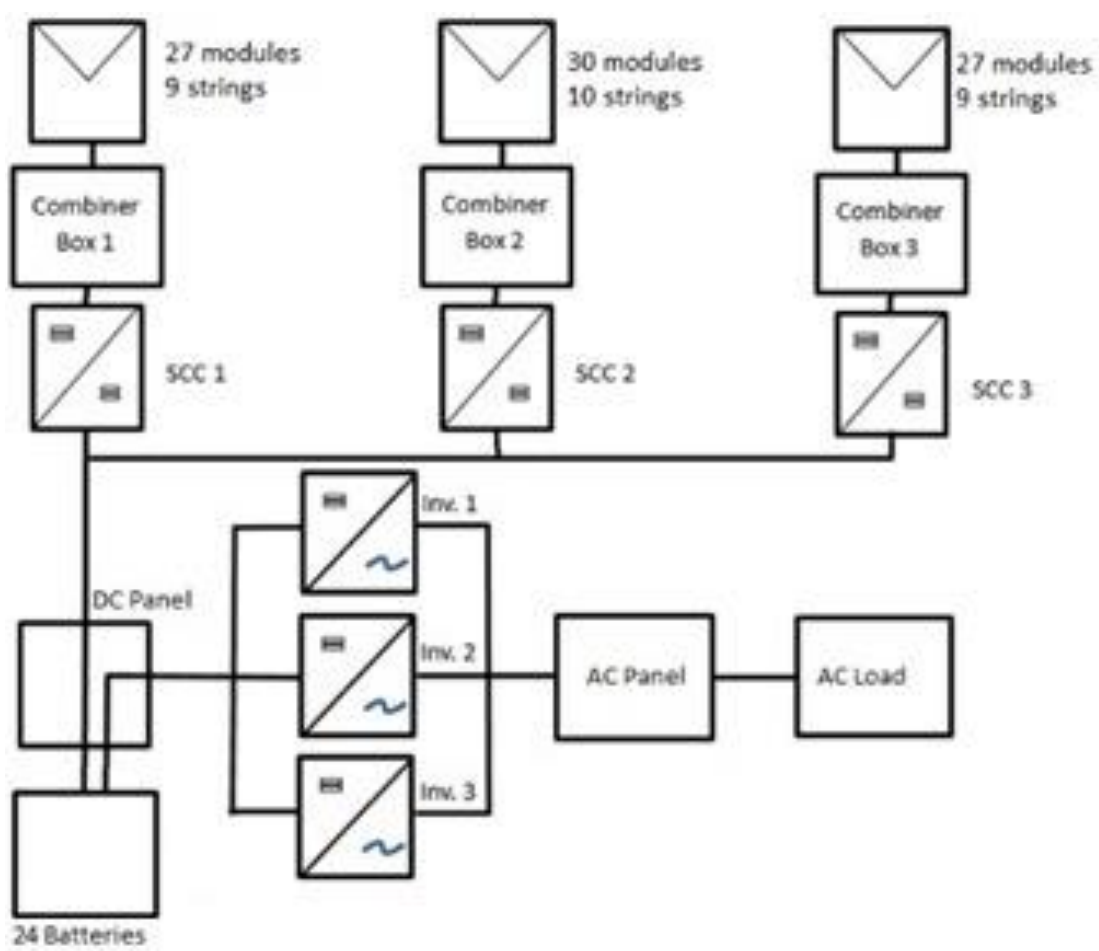

Figure 1. Configuration of $15 \mathrm{kWp}$ solar power system at Hoineno village

\section{Results and discussion}

There are several types of damage found in this study including snail trails, microcracks, soiling, discoloration, corrosion, backsheet chalking, delamination, and wires degration.

\subsection{Discolouration}

Discolouration is the most common type of degradation introduced by solar modules that have been operating for years in the field. Visual inspection results of Hoineno system are shown in Figure 2. This defect degraded the module's performance as it reduced the intensity of sunlight reaching the solar cells. Studies showed that discoloration could be caused by external factors, such as changes in humidity and temperature, and internal factors, namely poor quality of encapsulants.

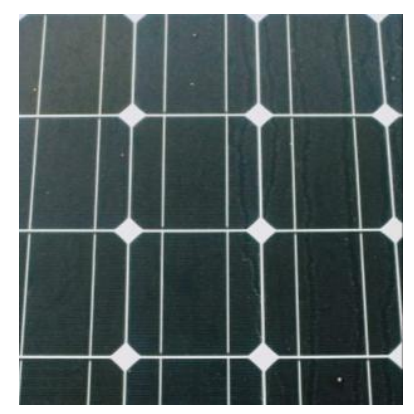

Figure 2. Discoloration of PV modules at Hoineno 


\subsection{Snail trails}

This degradation is classified as a new phenomenon characterized by discolouring of the silver grids across the surface of the cell or along the edge of the cell (Figure 3 ). In some cases, snail trails appear on modules that have only been installed for several months [8]. Other studies also found that snail trails growing on the cells are very slow [9].

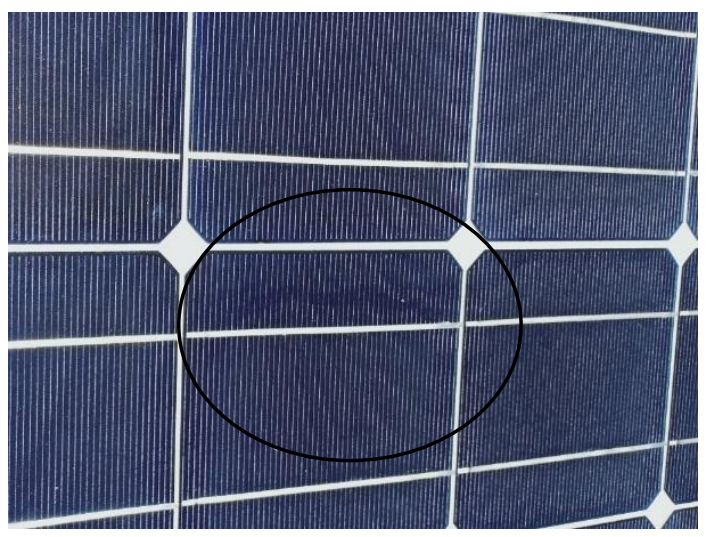

Figure 3. Snail trails of a PV module at the Hoineno off-grid system

\subsection{Microcracks}

Microcracks can occur due to the manual soldering process during manufacturing where the cell is subjected to mechanical pressure and heat that is too high. Under further pressure, after years in the field, the cracks can be larger and clearer for visual detection. Cracking solar cells can reduce module output. Photograph of microcracks of a PV module at Hoineno system is shown in Figure 4.

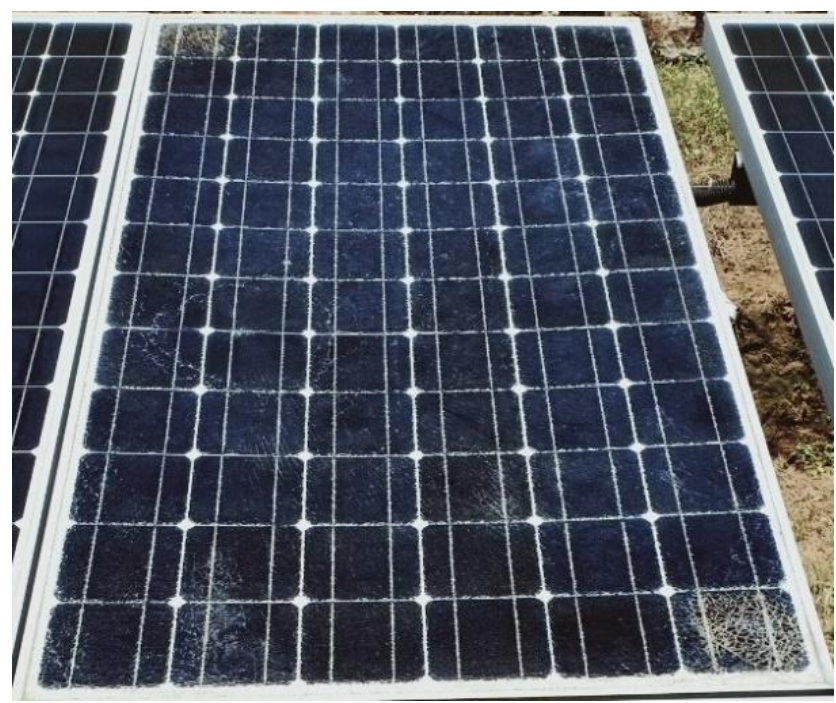

Figure 4. Microcracks of a PV module at Hoineno system 


\subsection{Corrosion on junction boxes}

Junction box is a terminal box located on the back of solar panel that are used as a place to connect several PV modules to be a string. A good junction box must be tightly closed so that water and other materials can not enter. keep corrosion in the terminal to a minimum, because it does not include incoming water. Visual inspection results show that the junction boxes of some modules are not tightly closed. As a result, corrosion occurs in the PV electrical terminals as shown in Figure 5.

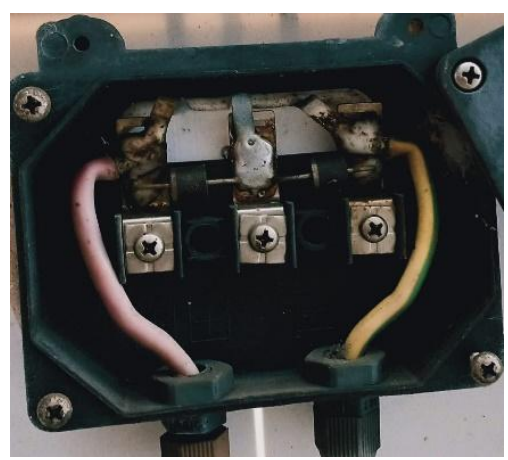

Figure 5. Corrosion on junction box of a module at Hoineno

\subsection{Soiling}

PV modules installed outdoor are exposed to various environmental conditions. One of the environmental factors that causes performance degradation is soiling. The PV modules deployed at Hoineno system also experienced the same situation. Soiling/dust attached on the modules is generated by wind and human activities around area of the modules. As shown in Figure 6, the modules have not yet been cleaned by the operator of Hoineno system. This condition, understandable, reduces the electric power generated by the modules. Dust that adheres to the surface of the modules prevents or reduces the intensity of solar irradiation that should be received by solar cells of the modules. If this is left unchecked, from time to time hot spots will arise which can cause permanent damage on the modules [10].

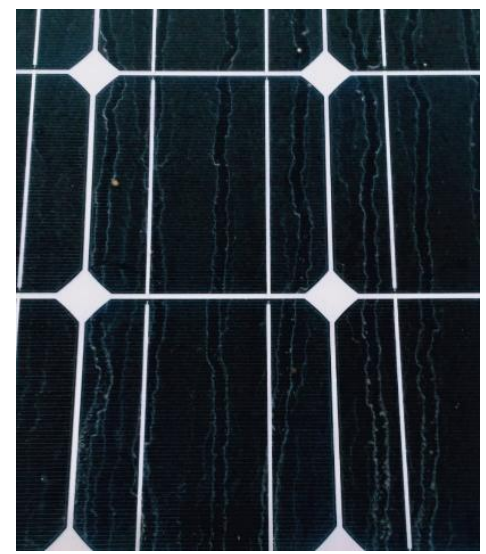

Figure 6. Soiling degradation of a PV module at Hoineno system 


\section{Conclusion}

Visual inspection is a method which commonly applied to investigate the degradation experienced by a PV module. A study conducted at the $15 \mathrm{kWp}$ off-grid PV system at Hoineno revealed that the modules had undergone several modes of degradation, namely, discoloration, snail trails, microcracks, corrosion on junction boxes, and soiling. Most of the degradation that arises was caused by natural factors such as changes in temperature, humidity, and chemicals. Meanwhile, dust which is a natural phenomenon needs attention from operators in the field. This is because it will reduce the module performance leading to economic losses.

\section{Acknowledgement}

The authors would like to thank Politeknik Negeri Kupang for the financial support through the RUTIN Research programme. A thank you also goes to Mr. Ferdi Tahun, operator of the system at Hoineno, for his assistance during this research.

\section{References}

[1] IEA: PVPS Trends 2016 in Photovoltaic Applications. Retrieved August 20, 2018, from http://iea-pvps.org/index.php?id=256 (2016).

[2] IEA: Renewables in global energy supply: an IEA fact sheet (2006).

[3] Deline, C.: Partially shaded operation of multi-string photovoltaic systems. In 2010 35th

IEEE Photovoltaic Specialists Conference (2010).

[4] Tanesab, J., Parlevliet, D., Whale, J., Urmee, T., \& Pryor, T.: The contribution of dust to performance degradation of PV modules in a temperate climate zone. Solar Energy, 120, 147157 (2015).

[5] Quintana, M. A., King, D. L., McMahon, T. J., \& Osterwald, C. R.: Commonly observed degradation in field-aged photovoltaic modules. Paper presented at the Photovoltaic Specialists Conference, 2002. Conference Record of the Twenty-Ninth IEEE (2002).

[6] M. A., Alonso-García, M. C., Vela, N., \& Chenlo, F.: Early degradation of silicon PV modules and guaranty conditions. Solar Energy, 85(9), 2264-2274 (2011).

[7] Köntges, M., Kurtz, S., Packard, C., Jahn, U., Berger, K., Kato, K., Iseghem, M. V.: Review of Failures of Photovoltaic Modules Report IEA-PVPS T13-01: 2014. International Energy Agency-Photovoltaic Power Systems Programme (2014)

[8] Djordjevic, S., Parlevliet, D., \& Jennings, P.: Detectable faults on recently installed solar modules in Western Australia. Renewable Energy, 67, 215-221 (2014).

[9] Sadoke, M., Benyoucef, B., \& Benmedjahed, M.: Assessment of PV modules degradation based on performances and visual inspection in Algerian Sahara. International Journal of Renewable Energy Research (IJRER), 6(1), 106-116 (2016).

[10] Tanesab, J., Parlevliet, D., Whale, J., \& Urmee, T.: Seasonal effect of dust on the degradation of PV modules performance deployed in different climate areas. Renewable Energy, 111, 105-115 (2017). 